\title{
Literature and Journalism in Portugal: The Major Contribution of Eça de Queirós ${ }^{1}$
}

\begin{abstract}
Using a cultural and transnational history approach, this paper aims to situate the origins of Portuguese journalism from 1865-1900 in a much broader set of literary practices. To understand the relationship between literature and journalism, it follows the trajectory of the novelist Eça de Queirós, an intellectual who had a keen perception of the historical context in which he lived (1845-1900). The fact that he lived abroad during most of his active life, working in consular posts (Havana, Newcastle, Bristol and Paris), enabled him to have access to the foreign press and gave him a clear perception of the different cultural geographies of Europe at the end of the $19^{\text {th }}$ century. Although this reading is only based on the perspective of one writer, the article argues, nevertheless, that Queirós' fictional and non-fictional writings offer us a renewed perspective on transnational literary journalism in the context of the emergence of mass culture.
\end{abstract}

\section{Keywords}

Portuguese press, $19^{\text {th }}$ century, journalism, literature, men of letters, Eça de Queirós.

\section{Introduction}

The second half of the $19^{\text {th }}$ century was possibly one of the most challenging periods in the history of Portuguese journalism. During this period, we witnessed diverse social changes, especially in urban areas, ranging from the consolidation of the tertiary sector to a move from trade to services, particularly in the intellectual field. In addition, the period was characterised by political instability and agitation, with the Republican political field's visible use of the power of the media. Finally, this period showed a heterogeneous context of fundamental changes at the end of the constitutional monarchy that contributed to the affirmation of journalism as a professional field ${ }^{2}$. 
These changes were of a technical, stylistic, sociological and professional nature. They began in Portugal in the middle of the $19^{\text {th }}$ century with Eduardo Coelho and Tomás Quintino's founding of the newspaper Diário de Notícias. This was an innovative newspaper that was very different from those in circulation. ${ }^{3}$ At the time, the press was dominated by opinion newspapers or specialised publications, and this new newspaper appeared as a different genre that aimed to reach a large and diversified public, similar to what had happened in French $18^{\text {th }}$-century journalism with the Petit Journal. ${ }^{4}$

Although still distant from the great technological revolutions that introduced the audio-visual media that would mark the whole of the $20^{\text {th }}$ century, the 1800 s offer a fascinating period for those who seek to understand the cultural and socio-discursive complexity of journalism as a public activity and autonomous profession. It was during this period that the newspaper appeared as a product for consumption with an indelible impact on public and private life, the development of public space and the emergence of mass communication. According to Luís Costa Dias and José Miguel Sardica, in the second half of the $18^{\text {th }}$ century in Portugal, the conditions were ideal for the emergence of a new paradigm of journalism. On the one hand, new press technologies made greater circulation possible, with reduced costs; on the other hand, the Portuguese press imported new styles, forms and genres from the United States, which led to the transformation of journalistic paradigms. These changes, which also had an impact on the organisation of the profession, were accompanied by an increase in literacy rates in urban centres throughout the country that, in turn, created the possibility of a broader reading public ${ }^{5}$. During the last two decades of the $19^{\text {th }}$ century, these conditions brought about that which Costa Dias has referred to as 'mass culture founded in the civilisation of the press' Around 1880, Lisbon, the country's capital, had 300,000 inhabitants and printed 50,000 copies of daily newspapers (a ratio of one newspaper per six inhabitants); in 1900, the city had 400,000 inhabitants, and the ratio increased to one newspaper per four inhabitants. According to José Miguel Sardica, there are facts that are most revealing: In 1880, there were around 200 newspapers published in Portugal. By the end of the 1890s, this number had doubled, and on the eve of the $20^{\text {th }}$ century, there were 592 newspapers, meaning that 'at the turn of the century, there was a surprising ratio of one newspaper for every 9160 inhabitants, far superior to England and France, where the ratio was $1 / 23000{ }^{\prime}{ }^{7}$

To understand this period in the history of Portuguese journalism, we need to consider two interconnected aspects: i) on the one hand, the relationship between journalism and literature (which was characterised by convergences, contaminations, tensions and symbolic disputes) and ii) on the 
other hand, the place of the Portuguese press in a transnational context (in which influences from French journalism and a new model of journalism stemming from the United States interconnected).

According to John Bak, 'at the end of the $19^{\text {th }}$ century, several countries were developing journalistic traditions similar to what we identify today as literary journalism or literary reportage'8. As a transnational phenomenon stemming from multiple journalistic traditions, the author shows that 'literary journalism evolved on three continents over the past hundred-plus years' ${ }^{\text {' }}$. Regarding the last decade, many scholars of different nationalities (Richard Keeble, John C. Hartsock, Giona Giles, Alain Vaillant, Marie-Ève Thérenty, Isabel Soares, etc.) have made a significant effort to legitimise literary journalism as an epistemologically autonomous discipline ${ }^{10}$. However, according to John Bak, 'international literary journalism still needs to establish its boundaries', and this is not an easy task, first because of 'the problems associated with defining a form that is more culturally bound than literature and more politically sensitive than journalism', and second, because literary journalism is an area that is 'continually evolving'11.

Using a cultural history approach, this paper aims to contribute to our understanding of the development of literary journalism by situating the origins of Portuguese journalism in the second half of the $19^{\text {th }}$ century within a much broader set of literary practices that encompass rhetorical models, discursive genres, processes of representation, reading protocols and social dynamics. To problematise and understand the relationship between literature and journalism at the dawn of contemporaneity, it follows the trajectory of the novelist and 'journalist' Eça de Queirós, an intellectual who had a keen perception of the historical context in which he lived (1845-1900). His writings enable us to follow pari passu the developments, fluctuations and dynamics of the emergence of journalism as a mediation field in modernity.

Throughout his life, Eça de Queirós collaborated closely with Portuguese and Brazilian newspapers and magazines, where he published fiction, open letters ${ }^{12}$, opinion articles and a vast number of chronicles. Simultaneously, the fact that he lived abroad during most of his active life, working in consular posts in Havana (Cuba), Newcastle, Bristol (UK) and Paris (France), enabled him to have access to the foreign press-which he paraphrased abundantly in his texts-and gave him a clear perception of the different cultural geographies of Europe at the end of the $19^{\text {th }}$ century, influencing his perspective on journalism as an emerging field. 
Although aware that this reading involves risks since it is based on the perspective of one writer, I believe, nevertheless, that Eça de Queirós's fictional, and especially non-fictional, writings of the second half of the $19^{\text {th }}$ century offer us a fresh perspective on transnational literary journalism in the context of the emergence of mass culture. Furthermore, by exploring the work of the journalist/ writer Eça de Queirós, this article follows the trend of diversification that characterises this field of studies. In the opinion of Nancy Roberts, 'over the past decade or so, scholars have admirably diversified literary journalism's canon through the study of individuals and subjects historically overlooked'13.

Indeed, one of the lines of development of the history of transnational journalism consists of the study of the transformation of the profession in view of the circulation of ideas, formats, discourses and agents among countries and cultures. Therefore, Eça de Queirós's vision of the changes in the world of journalism at the end of the $19^{\text {th }}$ century-whether in professional, discursive or textual terms-is intrinsically transnational.

\section{'Men of letters' versus journalists}

As happened in France and in most of southern Europe ${ }^{14}$, journalism emerged in Portugal in a hybrid territory, closely dependent on the literary and political spheres. The overlapping of these spheres determined the path that the Portuguese press would subsequently follow, and it especially shaped the construction of the professional field of journalism in Portugal. From the early $19^{\text {th }}$ century, newspaper and magazine newsrooms provided an entryway into the world of literature and politics. ${ }^{15}$ Writing for the newspapers was a routine activity for those who wanted to have a voice and make a name for themselves as a politician or literary author.

Jean Chalaby considers that one of the most significant aspects of French journalism in the $19^{\text {th }}$ century was the tight relationship between politics and literature. The author also affirms that journalism is a North-American invention (with objective discourse, texts centred on facts, formal and rhetorical structures, informative genres as news items and reporting), given that discursive practices in France were more 'undetermined and undefined' ${ }^{\prime 6}$. The intersection of journalism and literary and political fields is also visible in the history of Portuguese journalism, as seen in the presence of some of the 'big names' in Portuguese literature in the pages of $19^{\text {th }}$-century newspapers and magazines, such as Garrett, Herculano, Camilo, Eça, Ramalho, Antero, Fialho de Almeida and many others. 
Furthermore, Marcel Broersma, ${ }^{17}$ adopting a discursive and stylistic focus, demonstrates that from 1890 onward, a new style of journalism stemming from the United States received various reactions in Europe. On the old continent, southern countries such as Portugal, Spain, Greece and France offered greater resistance to North-American formulae than the countries of northern Europe. The cause of this was a new paradigm that engaged with the well-established culture that was characterised by a more professional model of journalism and a commercial- and business-oriented view of media fields. In Portugal, the history of the press of the last quarter of the $19^{\text {th }}$ century was marked by these tensions: the process of the journalist's professional self-nomination-later than in other countries-and the appearance of the first media 'empires', of which the newspaper O Século is an example.

Even within the movement pushing for the foundation of a professional association for journalism ${ }^{18}$, which contributed to the gradual emergence of the journalist as an autonomous professional, the connection between writers, politicians, men of letters and journalists persisted until the end of the century. It was only in the last decade of the $19^{\text {th }}$ century that references to writers or men of letters were eliminated from the names of those associations, which was, in itself, a sign of the impending transformation that would lead to changes in newsrooms and the professional reorganisation of the newspapers, from which writers were gradually phased out. ${ }^{19}$

The 'association movement' of the turn of the century-which is being studied in the context of the research project 'For a History of Journalism in Portugal'-is quite an eloquent example of these tensions $^{20}$. The Portuguese Press Association was founded in 1897 by three journalists, precisely as a reaction to the Association of Journalists that accepted only the 'aristocracy of the press,' such as distinguished literary figures, and excluded the majority of reporters and writers that were increasingly essential for running the newspapers. Concerning this issue, the editor of a major Portuguese newspaper regrets the fact that there was no agreement among the associations, which were divided by issues of class and affected by the division in the field of the press: on the one hand, intellectuals and, on the other, reporters from the popular class (such as typographers) or the middle class without symbolic weight or status (as informers and reporters):

A regrettable fact is that, from the beginning, the two Associations-of Journalists and of the Portuguese Press-were unable to reach an understanding, and their relations were pervaded by mutual mistrust. Indeed, it is difficult to understand how, within each newspaper, it was possible for the editor and the writer to be in perfect harmony and maintain a close relation 
with the reporter or informer, and [simultaneously] to reject each other and hold incompatible positions at the association level ${ }^{21}$.

What is important to retain from this debate is the fact that since the last quarter of the $19^{\text {th }}$ century, the story of the press in Portugal developed through moments of tension, on the one hand, with the cultured elite that had a certain idea of the mission of journalism and that from at least the period of the first Liberalism (1820) used newspapers for political and cultural purposes and, on the other hand, a new class composed of reporters, photographers and typographers that came from the urban middle classes and demanded professional autonomy.

Referring to the participation of men of letters in the field of journalism, Thomas Ferenczi sees the journalism of this period as a passageway, and Christian Delporte refers to it as an antechamber to literature or politics ${ }^{22}$. In a country like Portugal, with a limited audience and a weak book market, the profits gained from journalistic writing represented additional revenue that made up for the meagre earnings gained from book sales ${ }^{23}$. In his private correspondence, Eça de Queirós made several references to the fact that his job as correspondent was essential for balancing his finances. ${ }^{24}$ In 1896, he wrote to Alberto d'Oliveira:

As you well know, my friend, I am, I have been in these past few years, a regular writer for the Gazeta de Notícias in Rio [de Janeiro], receiving a steady salary. What I have sent the Gazeta in prose, in over four months, is not worth the value of a postcard. Since I didn't deliver the work, having scruples, I didn’t ask for any pay. But these payments are indispensable for my budget-and in order to receive them legitimately now, I have to send to Rio the tonnes of prose to which they correspond and that justify them ${ }^{25}$.

Regardless of the motivations that attracted men of letters to the world of the press, it is important to stress this point: A history of Portuguese literary journalism cannot leave out the problematisation and understanding of the tensions that existed within this cultural community in the last half of the $19^{\text {th }}$ century, at a time when writers and intellectuals lived side by side with the emerging professional class of reporters and journalists ${ }^{26}$. In the last quarter of the century, socially privileged journalists, those that the historical narrative never forgets, were, as a rule, renowned literary figures or exceptional editors of major publications. ${ }^{27}$ However, little is known about the writers and reporters, and a study on their social background, education and training and the way in which they made their entrance 
into the newsrooms is still to be done. Nonetheless, they were pivotal figures at a time of the mass expansion of the press, when it began to be based on a sustainable business model.

As I will explain below, the opinions that Eça de Queirós included in his press articles on newspapers, journalists and the press as a whole enable us to understand this tension better.

\section{Eça de Queirós and his unique career}

Like many $19^{\text {th }}$-century Portuguese writers ${ }^{28}$, Eça de Queirós maintained a very close relationship with the world of the press throughout his active life. His first literary pieces (feuilletons) appeared in the Gazeta de Portugal (Portuguese Gazette), a daily newspaper that Augusto Teixeira de Vasconcelos (its political director) and Mendes Leal (its literary director) founded in 1862 and that existed until 1868, and in which some of the most influential Portuguese columnists and writers collaborated. ${ }^{29}$ From 1877 to 1878, he was the correspondent for Atualidade, a newspaper that the Republican cell of Porto (the second most important city in the country, situated in Northern Portugal) published, and between 1880 and 1898 for the important Brazilian newspaper Gazeta de Notícias, with which he maintained a more active collaboration ${ }^{30}$. He was the editor and sole writer of a local political newspaper-Distrito de Évora ${ }^{31}$-embodying what Francis Balle calls the $19^{\text {th }}$-century ideal of the 'one-man newspaper'32. Eça de Queirós was also the mentor and editor of the Revista de Portugal ${ }^{33}$, an editorial project of exceptional quality inspired by the French Revue des Deux Mondes ${ }^{34}$; as Helena Santana explains in the introduction to the critical edition of the Queirosian texts of that journal, this was a patriotic and national project, as even the name of the publication indicates. Valorising the best of what was being produced in areas ranging from literature to criticism and passing through science, history and politics was a way to offer a high-quality product to Brazilian and Portuguese readers and was simultaneously a way to elevate the morale of the country, projecting an image of progress and culture. From this follows that in the open letter, written to ask the national press to publicise its publication, Eça insisted on the patriotic aspect of the project, a good argument through which he hoped to persuade his editorial 'colleagues' to reserve journalistic space for the dissemination of his Revista. He also collaborated with the Revista Moderna, a periodical that the Brazilian Martinho Botelho published in Paris between May of 1897 and April of 1898. Lastly, given that Eça de Queirós is a major figure in Portuguese literature, it should be remembered that he also published important fictional texts in the print media of his time. ${ }^{35}$ 
This listing confirms the persistent, lasting and multifaceted connection of Eça de Queirós with the world of the $19^{\text {th }}$-century press, a connection that supports the argument presented here. Living in England and France-from 1874 to 1879 in Newcastle-on-Tyne, from 1879 to 1888 in Bristol and from 1889 to his death in 1900 in Paris-and enjoying unparalleled access to the foreign press, Eça de Queirós was an avid reader of mostly French and British newspapers and magazines, and this gave him a keen perception of the different cultural geographies of fin-de-siècle Europe. Alan Freeland studied a less familiar aspect of his writing-his consular correspondence from England-and highlighted the importance of Eça de Queirós's foreign experience in this writing, namely the fact that he had the opportunity to follow the miners' strikes, as well as the social problems of progress and industrialisation. This focus on social issues in reality illustrates how he was influenced by French naturalism, as the following quote shows:

Eça's four years in Newcastle coincide with the period in which he was most clearly committed to a naturalist aesthetic and closest to the 'scientific' assumptions of positivism. In particular, the second version of O Crime do Padre Amaro and O Primo Basílio are works which carry strong implications of determinism. ${ }^{36}$

Most of the texts written from Newcastle for the newspaper A Atualidade (1877-1878) were inspired by English newspapers, from the venerable Times of London, The Daily Telegraph, Daily News, Standard and The Morning Post, which Eça de Queirós called 'the great newspapers-character newspapers', indicating his admiration for British journalism ${ }^{37}$ - to social and satirical periodicals such as Fun, Whitehall Review and Vanity Fair, where Eça de Queirós found interesting stories and spicy episodes with which to entertain his readers. The 15 texts that Eça sent from Newcastle had very diverse themes, dealing with different aspects of English politics, public affairs, society and cultural life. In these 15 texts, we also perceive a preoccupation with offering readers current information on specific topics, as would be expected from a news correspondent. A good example of this urgency for current affairs is the Russian-Turkish conflict and the way it was presented in these texts: Of the 15 letters sent to the newspaper, 12 developed this international political theme that Eça de Queirós followed with enthusiasm from the beginning, always aiming to combine information and opinion and showing a concern for the way in which England was handling its participation in the conflict. The other political issues that Eça approached in his writing were also governed by the criteria of actuality and relevance: aspects of French politics (the deterioration of relationships between France and Germany, the MacMahon 
coup in France, the French elections), the labour demands in England, England's annexation of the Transvaal and Egypt, the death of Pius IX and the election of Leo XIII, the American labor riots, hunger in India, etc.

These were some of the themes of British news that Eça de Queirós reinterpreted, taking grand liberties in doing so as he adapted them from the reader of $A$ Actualidade. This was one of the ways in which Eça chose to write for newspapers without neglecting his natural role as a writer: Using facts from international current affairs, he practiced narrative formulae, embellished stories, constructed satirical contexts and created characters. As such, the ‘journalism’ of Eça de Queirós corresponded to the $19^{\text {th }}$-century model in that fiction, opinion and facts mingled in the same editorial space. ${ }^{38}$

The press, journalism and the 'media' revolution of this period did not escape his notice, and he showed a particular awareness of this new social and cultural force that emerged in the second half of the $19^{\text {th }}$ century, writing numerous critical reflections on newspapers, journalists and journalism that constituted, in the words of the Brazilian scholar Elza Miné, 'his theory of journalism'39. According to Isabel Soares, Eça de Queirós and other intellectuals, members of the well-known 'Generation 70’-such as Ramalho Ortigão and Oliveira Martins-participated in a type of reinvention of old journalistic practices by 'importing the "new” journalism made popular by W. T. Stead and Henry Mayhew'40. Furthermore, Vanda Rosa, supporting Isabel Soares's thesis, argues that the journalism that these men of letters practiced 'intended to bring journalism closer to the public and expunge it from its impartiality', considering it 'a vehicle to expose the problems of Portuguese society: political corruption, high levels of illiteracy and poverty' 41 .

Partially agreeing with this perspective, I would argue that the study of the case of Eça de Queirós in the context of the Portuguese and European cultural fields requires a more careful and nuanced approach. There are essentially three arguments for this that need to be considered. Firstly, the author's continued collaboration with the press was highly pragmatically motivated: It was an additional means of earning money. Secondly, it is known that Eça de Queirós used these journalistic texts as writing laboratories in which he explored plots, sketched characters and created story worlds (many of them later developed in his novels). Thirdly, $19^{\text {th }}$-century Portuguese journalism had not yet developed a set of professional procedures and techniques-such as objectivity and impartiality-and thus remained an opinion press until the end of the century at least.

According to Melissa Score, the 'new journalism' 'was persuasive, opinionated and sensational. It displayed characteristics of the American mass-circulation press, including eye-catching headlines 
on newspaper front pages. ${ }^{32}$ If it is true that the collaboration of Eça de Queirós with the press was fundamentally opiniated, it was far from assuming the characteristics of the performative practices of North-American journalism, which Eça, in fact, distrusted.

It is this interplay of forces-on the one hand, the intellectual elite that dominated the world of newspapers, and on the other, new groups of professionals who fought for autonomy, that is, the journalistic ideal with a civic and pedagogical dimension, and contrarily, professional journalism focused on providing news stories that professionals had written-that partly explains the extremely negative representation of the journalist in the literature of the period. Some of Eça de Queirós's major novels, such as O Crime do Padre Amaro, O Primo Basílio, Os Maias, A Capital give us a fictionalised image of the power of influence that certain Lisbon newsmen exerted, as well as their promiscuous relations with political decision-making circles. In his fiction, journalist characters were, as a rule, the result of a distorted representation characterised by low moral standards-a lack of scruples, a tendency toward corruption and, particularly, submission to power and money. A journalist in his work also usually displayed condemnable social behaviours, a lack of ethics and defective technical skills. Although a caricature, this image points to what Eça de Queirós perceived as the main shortcomings of this class. This portrayal can be seen as a symptom of the growing unease that the educated elites, i.e., writers, men of letters and intellectuals on the one hand, and on the other, the mass of professionals who had begun to take over the newsrooms and demand an autonomous status, experienced in journalism.

The fictional representation of journalists in the narratives of Eça de Queirós found an echo in literature in France, which also presented a dual and antagonistic view of the world of the press. On the one hand, we find an extremely negative image representing newspapers as organs of corruption, lies, defamation and moral prostitution, and on the other, we have the reverse image, which reflects the ideal of journalism, praising its moralising, democratic and educational mission ${ }^{43}$. This dual representation is in sync with the opinions that Eça de Queirós expressed about journalism, newspapers and journalists in his letters, chronicles and newspaper articles.

With his power of observation and sharp mind, the author understood early on that journalism could be a powerful tool for social change in his time. Accordingly, he focused his attention on the press, in addition to other areas of Portuguese and European society, such as politics, finance, education and the family. The critique of the press conveyed in the author's texts until the end of the century, including in some of his fictional work, is also found in the work of French writers such as 
Balzac, Zola, Stendhal and Victor Hugo, all of whom experienced an ambivalent situation resulting from their love-hate relationship with the press. ${ }^{44}$

Although Eça de Queirós’s analysis was not as systematic or even as deep as that of his French counterparts, it nevertheless appeared in a fragmentary and dilettantish manner in many of his articles. Benefiting from the freedom of the press experienced in Portugal from the period of the 'Regeneration' (which occurred between 1851 and 1868) ${ }^{45}$, Eça de Queirós devoted a significant part of his contributions to the Portuguese and Brazilian press to social and political critique, and, therefore, journalism itself was only one of his targets. ${ }^{46}$

The positions that Eça de Queirós assumed publicly in the last three decades of the $19^{\text {th }}$ century allow us to have a clearer sense of the radical tensions that were present in this new field of modernity: the conflict between the model of journalism practiced in countries of southern Europe and the model of the North-American 'new journalism', as well as the tensions between men of letters-writers and politicians-and the elite and new professional groups that began to provide content for the large media such as the newspapers O Século and O Mundo. It is interesting to see that as we approach the last quarter of the century, his diagnosis became increasingly pessimistic and disenchanted. He felt that the romantic and liberal ideal of the press as a civilising force and the journalist's educational and civic mission, which he vigorously defended in 1867 in the pages of the local paper Distrito de Évora, remained unfulfilled:

Journalism (...) is the motor of the spirit. It discovers new and fecund social relations among the peoples of the same continent; it promotes and strengthens the moral solidarity that connects men, the fraternity that touches them; journalism teaches, guides, enlightens above all; it is the great builder of the future (...). ${ }^{47}$

Eça de Queirós's change of heart became apparent when, three years later, he published his first diatribe against the press in the newspaper A República: ${ }^{48}$ He accused it of a lack of principles, vacuousness, an absence of aesthetic qualities, overuse of a hackneyed rhetoric and subjection to the established powers; he criticised the frivolousness of its content, which was pedestrian and limited to fait divers, as well as its excessive personalisation.

It is, however, in the articles that Eça de Queirós wrote for the Gazeta de Notícias of Rio de Janeiro in the last decade of the century (1888-1896) that he adopted a more corrosive discourse on 
the workings of this new public space. Replicating the previously discussed French critical discourse, he wrote an increasing number of diatribes against the vices of the press-its superficiality and shallowness, its excessive power in the formation of public opinion, the celebrity culture it promoted and so on.

Eça de Queirós’s journalistic vision at the turn of the century perceived journalism as a European phenomenon, giving it a broader and more global perspective. In many of the chronicles that he sent to the Brazilian newspaper, the author-who ironically considered himself 'a sort of journalist'- covered themes such as the press, journalists and the new dynamics of the public sphere. The relationship between newspapers and journalism was ambiguous: As an intellectual and writer, Eça de Queirós needed to maintain his collaboration with the newspapers and magazines of the time (whether for financial reasons or public recognition), but he was also perfectly aware that at the end of the century, he was a 'species at risk of extinction', very different from the professional journalists and reporters that worked in the newspapers.

Especially during the years that he lived in Paris (1889-1900), he no longer criticised Portuguese pettiness nor caricaturised the flaws and backwardness of the nation, much less wrote in defence of journalism as an idealised civilising force. His ironic perspective and ruthless criticism were directed toward more global phenomena, targeting societies held as more 'civilised' and evolved than the Portuguese. One of these phenomena was journalism.

The series of letters that appeared in the section 'Echoes of Paris' of the Gazeta de Notícias and that the author published in 1894 covering the news of the death of President Carnot illustrate well how the writer was already sensitive to the growing power of the press: It used all strategies possible to create emotional and affective ties with readers, capturing their curiosity through sensationalism and hyper-sensibility, reducing their capacity for analysis and transforming high-impact political news into small domestic dramas. The journalist condemned the newspapers' sensationalist language that only served to exalt emotions, precluding the reader's fundamental critical distance. This is the thought process of someone with a transnational perspective on journalism, whose contact with the international press enabled him to understand the new nuances that journalistic discourse would acquire at the turn of the century when journalistic agencies were becoming more professionalised, and capturing a reading public depended greatly on speaking to the readers' sensitivities and emotions.

On the other hand, a careful reading of Eça's vast epistolary collaboration with this Brazilian newspaper shows the persistence of an array of discursive and narrative strategies that were closer to 
the pre-industrial journalistic ideal than to adherence to new standards of writing: The persistent reliance on the epistolary form, the narrative propensity of the texts, the persistence of descriptive discourse, the literary form of some of the chronicles, the thematic playfulness and a strong presence of personal opinions and subjective discourse were all typical strategies of literary journalism that resisted following North-American models. Eça de Queirós, adopting the attitude of the elite of certain European countries, saw with pessimism and distrust the Americanisation of journalism. ${ }^{49}$

The issue involved not only two antagonistic conceptions of journalism but also the confrontation of dominant positions within the cultural field of the press, one derived from a progressivist perspective that viewed journalism as a pedagogical and civic practice based on values and ethics of citizenship, and the other, more modern and aligned with the innovations imported from North-American journalism, that focused much more on information and with a business model based on mass audiences. ${ }^{50}$ The relationship of writers - men of letters and intellectuals-with the press was therefore a double-edged sword: If the newspaper enabled them to have a voice in the public space, they could make a name for themselves in the market and gain the power of influence, but it was this same rapidly changing media universe that would bring about a crisis in the symbolic status of the $19^{\text {th }}$-century intellectual.

The letter that Eça de Queirós wrote in 1886, which was published as a preface to Azulejos, a short story collection that his friend the Count of Arnoso wrote, gives us a clear idea of the author's views regarding the transformations of that new public space. These transformations were accelerated by the technological revolution and a whole new urban and cultural environment marked by mass communication, where the printed object became the centre of social and cultural life. In this text, Eça de Queirós conveyed a remarkably modern viewpoint, writing at length about the massification of the press and the resulting change in the relationship between the writer and the audience. This was a paradigmatic text that foreshadowed some of the ideas that Gabriel Tarde published later in his 1901 book L'Opinion et la Foule: ${ }^{51}$

Afterwards, on a July morning, the Bastille was taken. Everything was solved, and a thousand violent new things emerged, changing the moral configuration of the Earth. Democracy arrived; gas lighting appeared; free and compulsory instruction came into being; the Marinoni machines that print one hundred thousand newspapers per hour were installed; Clubs, Romanticism, Politics and the Collotype sprang up. Everything started to be made by 
means of steam and cogwheels-and for the great masses. That marvellous thing called the individual, with such a delicate mechanism, disappeared; and the crowds began to move, governed by instinct, by some interest or enthusiasm. It was then that the reader vanished (...), and in his place the man of letters came face to face with that rabble called the public, which reads aloud and in a hurry in the humming streets. ${ }^{52}$

This preface, which is interesting from different points of view, contains the guiding ideas underlying the approach taken in this presentation: The miscegenation of literature and journalism is one of the keys for reading and understanding the inception of journalism in some southern European countries, and at several levels, this had consequences that extended far beyond the period on which I focus here.

If the contribution of men of letters, or later intellectuals, was decisive for the configuration of journalism as a professional field, the relationship between the two fields in conflict-the press and literature-was broader and more profound and was not limited to the symbolic tension between professional classes or status. In truth, there were also stylistic, rhetorical and textual implications for literature, as well as for journalism.

The field of $19^{\text {th }}$-century literature was influenced by the press not only through the emergence of new genres, such as pamphlets or serialised novels or current affairs novels, but also through the way in which writers began to perceive literary writing and the construction of these narratives, obeying the logic of fragmentation, serialisation, brevity and heterogeneity and adapting to a new public with diverse tastes, cultural habits and horizons and new media formats that radically altered practices of reading and sociability.

The serialised novel, the first mode of capitalist production in Portuguese fiction, was constituted as an ambiguous and dual object for the writer: If it guaranteed public recognition and ensured a definitive space in the pages of the newspaper, it simultaneously represented a step toward literature of an inferior quality, subject to the tastes and expectations of the reading public ${ }^{53}$ and subjected to the periodic and fragmented system of the press. The serialised novel especially represented an adaptation of literary art to the format and periodicity of the newspaper: Subject to the logic of a serialised and fragmented publication, it adapted and modelled these practices, 
innovating new narrative codes and demanding from the reader new and different reading competencies.

In my opinion, this influence was very broad, as I believe that from the point of view of literary periodisation, the influence of journalism is visible, especially if we consider the emergence of realism and naturalism as a tributary product, in part, of journalism: observing reality and describing, critiquing and painting it as it is. ${ }^{54}$ I believe that the practice of writing in a newspaper also contributed to modelling the way in which writers perceived their work and led to greater artistic engagement in political and social issues. When in 1871 Eça de Queirós defined realism as a new artistic expression, he defended it by saying that it would be the expression of the period, that it should proceed through experience and, especially, that it should pursue ideals of truth and justice-the same ideals that as redactor of the newspaper Distrito de Évora in 1867, he defended regarding journalism.

\section{Conclusions}

This text aimed to show that Eça de Queirós's work is essential to understanding the history of the Portuguese press during the second half of the $19^{\text {th }}$ century, especially when studied from a transnational perspective. At a time when the world of journalism was also the world of writers, and literature and journalism were fields in conversation one with the other, this approach argues that case studies such as those of this author have much to contribute to the understanding of a literary and comparative history of the Portuguese press.

The life and works of Eça de Queirós, especially his journalistic texts, have been studied in different fields, both within and beyond Portugal. Building on this work, the approach taken in this study brought together several angles that are usually treated separately, showing that the study of the 'journalistic' activity of this author needs to be understood within an interdisciplinary and transnational framework that sheds new light on its different aspects. Firstly, it showed how the privilege to travel the world was a situation that gave him the necessary distance to re-centre his criticism of his country and, simultaneously, allowed him to deconstruct some of the myths concerning two other European countries that at the time were symbols of 'progress' and 'civilisation'. ${ }^{55}$ Furthermore, it pointed out how Eça de Queirós was a corresponding 'journalist' for 
whom newspapers were mostly an atelier for writing, a means to share opinions and a bridge to readers who spoke Portuguese and to whom he reported about his experiences abroad. Finally, this analysis showed how Eça de Queirós as a novelist was inspired in terms of themes, style and idiosyncrasies by European-and especially French-literature, as well as by the French and English presses, even paraphrasing them at times.

In line with a cultural history approach ${ }^{56}$ and adopting a transnational perspective, this article demonstrated, therefore, that a comparative literary history of Portuguese journalism can explain many aspects of its formation, configuration and autonomisation. It can also shed light not only on the configuration of professional autonomy and emerging discursive genres and procedures but also on the affirmation of journalism as a political and cultural power. If the contribution of men of letters, and later intellectuals, was decisive for the construction of journalism as a professional field, the relationship between the two opposing fields of the press and literature was broader and deeper and cannot be reduced to a symbolic struggle for status between professional classes.

This, however, is a topic for further investigation, as there are questions to be pursued from a cultural and transnational perspective. That is, the 'literary journalism' of the Portuguese $19^{\text {th }}$ century had stylistic, rhetorical and textual implications for both literature and journalism that challenged national and disciplinary boundaries alike.

\section{Notes}

1. The research for this paper was conducted as part of the project 'For a History of Journalism in Portugal' (PTDC/COM-JOR/28144/2017), funded by the Portuguese Foundation for Science and Technology (FCT).

2. See Luís Augusto Costa Dias, "Personagens inventadas: Jornalismo e ficção na I Grande Guerra mediática (1914-1918)," Mediapolis. Revista de Comunicação, Jornalismo e Espaço Público 6 (2ºm, 2018): 41-59, and José Miguel Sardica, “O poder visível: D. Carlos, a imprensa e a opinião pública no final da monarquia constitucional,” Análise Social, 203, XLVII (2. Sem., 2012): 344-368.

3. About this Portuguese newspaper, Paula Miranda argues, 'At the time of the appearance of Diário de Notícias, the Portuguese journalistic panorama was fundamentally characterised by the existence of opinion newspapers of a doctrinal nature, which reflected the battles fought in the political domain and, on the other hand, by specialty newspapers in several branches.' (Paula Miranda, As Origens da Imprensa de 
Massas em Portugal: o Diário de Notícias (1864-1889). Dissertação de Mestrado em Estudos Históricos Europeus (Évora, 2002): 24.

4. This French newspaper that Moïse-Polydore Millaud created in 1863 was launched at a very low price (un sou) and came to revolutionise the French press, making it more competitive and massified. Its editorial strategy was to transform the newspaper into an attractive consumer object, exploring products that were easy to consume, such as fait divers and novels. (See M. Antónia Paz Rebollo, "O Jornalismo em França," in História da Imprensa, ed. A. Pizzaroso Quintero (Lisboa: Planeta Editora, 1996): 153-186.

5. According to Costa Dias, in 1884, in the three main cities on the coast of Portugal-Porto, Coimbra and Lisbon-the rate of literate male citizens was over 54\% (Luís Costa Dias, "Lire au coin de la rue ou l'entrée du Portugal dans l'ère médiatique," Le Temps des médias, no. 32, [Printemps 2019]: 201-218).

6. Luís Costa Dias, "Do claro busto de Minerva à dupla face de Jano, ou os anos dourados da imprensa," in Roque Gameiro na Imprensa, ed. C. Gouveia (Amadora: Casa Roque Gameiro): 7-17.

7. Sardica, “O poder visível,” 349.

8. Jon Bak, “Toward a Definition of International Literary Journalism,” BJR 13, no. 3 (2017): 215.

9. Bak, “Toward a Definition”, 227.

10. Richard Lance Keeble, “Literary Journalism as a Discipline: Tom Wolfe and beyond,” BJR 14, no. 3 (2018): 862-881.

11. Bak, “Toward a Definition”, 222.

12. In the $19^{\text {th }}$ century, the open letter was a frequently used genre, namely for famous writers such as Émile Zola who published, in 1898, the well-known letter J'accuse. Michael Warner, in The Letters of the Republic, in which he demonstrated the important role of the press in the consolidation of an American public sphere in the 18th century, mentions the relevant space that the pamphlet letter occupied in the public debate on legislative and political issues: 'In the colonial period, by far the most popular genres for political debate were the epistolary pamphlet and the dialogue'. (Michael Warner, The Letters of the Republic [Cambridge and London, Harvard University Press, 1995]: 40).

13. Nancy L. Roberts, "Literary Journalism Past and Future: A Journey of Many Miles in Intriguing Directions," Literary Journalism Studies, no. 2 (Fall, 2018): 63.

14. Luís Augusto Costa Dias and Ana Teresa Peixinho, "O intelectual, o artista e as massas na cultura portuguesa finisecular,” Estudos do Século XX, no. 18 (2018): 136-151; Jean Chalaby, “O Jornalismo como invenção anglo-americana. Comparação entre o desenvolvimento do jornalismo francês e anglo-americano (1830-1920),” 
Media \& Jornalismo, no. 3 (Outono/Inverno 2003): 29-50; Thomas Ferenczi, "L'invention du journalisme en France," in Naissance de la presse moderne à la fin du XIXe siècle (Paris: Plon, 1993); Joseph Jurt, "Le siècle de la presse et la littérature en France," Romanistische Zeitschrift fur Literaturgeschichte, 37 (2013), H. 3/4: 275-305.

15. In her analysis of the Portuguese intellectual elites of the first half of the $1^{\text {th }}$ century, Lima dos Santos argues that 'to work in journalism (and particularly in political journalism) meant entering a promotional path which, in the new era, had for underprivileged young people a power of attraction comparable to that of the ecclesiastical career in the old regime'. (Maria de Lurdes Lima dos Santos, Intelectuais Portugueses na primeira metade de oitocentos [Lisboa: Editorial Presença, 1985]: 332).

16. See Chalaby, "O Jornalismo".

17. See Marcel Broersma, “Journalism as Performative Discourse. The Importance of Form and Style in Journalism," in Journalism and Meaning-making: Reading the Newspaper, ed. V. Rupar (Hampton Press, 2010), 15-35.

18. About the early history of international journalist organisations from 1894, see Jonas Bjork, "First Internationals: IUPA and PCW (1894-1936)," in A History of the International Movement of Journalists, ed. Kaarle Nordenstreng et al. (New York: Palmgrave Macmillan, 2016), 42-79.

19. Rogério Santos, “Alberto Bessa e a sua história do jornalismo-uma memória de cem anos," in Atas do III SOPCOM, VI LUSOCOM e II Ibérico (Lisboa: SOPCOM): 197.

20. See also Rogério Santos, "Alberto Bessa e a sua história do jornalismo-uma memória de cem anos," in Atas do III SOPCOM, VI LUSOCOM e II Ibérico, Vol. IV. (Lisboa: SOPCOM, 2004): 193-201.

21. Alfredo Cunha, Jornalismo Nacional. Das malogradas Associações de Imprensa à alvitrada Ordem dos Jornalistas Portugueses. (Lisboa: s/n, 1941): 26. Translation by the author.

22. Christian Delporte, Histoire du Journalisme et des Journalistes en France (du XVII e siècle à nos jours) (Paris: P.U.F. Col. «Que sais-je?», 1995): 17; Thomas Ferenczi, L’invention du journalisme en France. Naissance de la presse moderne à la fin du XIX'e siècle. (Paris: Plon, 1993): 29.

23. De Lurdes Lima dos Santos, Intelectuais Portugueses.

24. As Carlos Reis explains, referring to Eça's correspondence from Paris, 'n'oublions pas que ces collaborations journalistiques répondaient aussi à la nécessité de gains supplémentaires, ressentie par un Eça que harcelaient les difficultés financières, aggravées par les exigences d'une famille déjà relativement nombreuse, dans une ville chère comme Paris’ (Carlos Reis, Eça de Queirós Consul de Portugal à Paris 1888-1900. (Paris: Centre Culturel C. Gulbenkian, 1997): 110. 
25. Eça de Queirós, Correspondência, ed. Guilherme de Castilho, (Lisboa: I.N.C.M, 1983): 360. Translation by the author.

26. Luís Augusto Costa Dias, "Elites intelectuais," in Dicionário de História da I República do Republicanismo, ed. Fernanda Rollo (Lisboa: Assembleia da República, 2014): 1114-1117.

27. 'This is the case of António Rodrigues Sampaio, who worked exclusively as a journalist, and who served several times as a member of parliament, minister and even prime minister; of José de Sousa Bandeira, respected and admired among intellectual and social circles; of Teixeira de Vasconcellos, Lopes de Mendonça, Pinheiro Chagas, Latino Coelho, Rebelo da Silva, Mendes Leal (...).' (José Tengarrinha, História da Imprensa Periódica Portuguesa. $2^{\text {nd }}$ ed. (Lisboa: Caminho, 1989): 192.

28. Since the beginning of the century, all great Portuguese writers collaborated in newspapers, founded magazines, intervened in the public space through the press: Almeida Garrett, Alexandre Herculano, Camilo Castelo Branco, Ramalho Ortigão, Fialho de Almeida and many others (see Tengarrinha, História da Imprensa, 192).

29. In fact, his first literary pieces appeared in the Gazeta de Portugal: They were written between 1866 and 1867, and they are now published and edited as Textos de Imprensa I (da Gazeta de Portugal) (Eça de Queirós, Textos de Imprensa I (da Gazeta de Portugal). Critical edition by Ana Teresa Peixinho (Lisboa: INCM, 2004). About this newspaper, see also Gina Guedes Rafael and Manuela Santos. Jornais e Revistas Portugueses do Séc. XIX. (Lisboa: Biblioteca Nacional, 2001): Vol. I.

30. See Eça de Queirós, Textos de Imprensa IV-da Gazeta de Notícias. Critical edition by Elza Miné e Neuma Cavalcante (Lisboa: INCM, 2002).

31. Ibid.

32. Francis Balle, 'Médias et Société'. De Gutenberg à Internet, $8^{\text {th }}$ ed. (Paris: Monchrétien, 1997), 47.

33. About this magazine, see Maria Helena Santana, "Introdução," in, Textos de Imprensa VI (da Revista de Portugal) (Lisboa: INCM, 1995), 15-48.

34. The Revue des Deux Mondes was a famous Parisian publication that appeared in 1829. Like the Revue de Paris, it published only work by major figures in culture and literature and was, therefore, a model and elitist magazine. On the important role it played in the French press, see Marie-Ève Thérenty, "Pour une histoire de la presse au XIX ${ }^{\mathrm{e}}$ siècle,” Revue d'Histoire Littéraire de la France, 103 ${ }^{\text {rd }}$ Année, no. 3 (Juillet, Sept., 2003): 92; Marie-Ève Thérenty and Alain Vaillant (Dirs.). 1836. L’An I de l'ère médiatique’. Analyse littéraire et historique de La Presse de Girardin. (Paris: Nouveau Monde Editions, 2001): 31-32. 
35. Several of the author's novels were published in the press: For example, his major novels first appeared in serial format in newspapers and magazines (O Crime do Padre Amaro [1975]; O Primo Basílio [1878]; O Mandarim [1880]; A Relíquia [1887]; Os Maias [1888]) (Ernesto Guerra da Cal, Lengua y Estilo de Eça de Queiroz-Apêndice Bibliografía Queirociana sistemática y anotada e iconografia artística del hombre y la obra, (Tomo $1^{\circ}$ Coimbra: Imprensa da Universidade de Coimbra, 1975): 65-66.

36. Alan Freeland, “Eça de Queirós: Consular Correspondence from Newcastle," Portuguese Studies, Vol. 2 (1986): 100.

37. Eça de Queirós, Cartas de Londres. Obras de Eça de Queiroz. (Porto: Lello \& Irmão-Editores, 1986), 983, 885-997.

38. About literary journalism during the $19^{\text {th }}$ century, see Matthew Rubery, The Novelty of the Newspapers: Victorian Fiction after the Invention of the News (Oxford: Oxford University Press, 2009), and Melissa Jean Score, The Development and Impact of Campaigning Journalism in Britain, 1840-1875: The Old New Journalism [Thesis] (University of London, 2015).

39. Elza Miné, Páginas Flutuantes-Eça de Queirós e o Jornalismo do Século XIX. (S. Paulo: Ateliê Editora, 2000), 16; see also Ana Teresa Peixinho, A epistolaridade nos Textos de Imprensa de Eça de Queirós. (Lisboa: INCM, 2010), 133-148.

40. Isabel Soares, “Literary Journalism's Magnetic Pull: Britains's 'New' Journalism and the Portuguese at the fin-de-siècle," in Literary Journalism Across the Globe: Journalistic Traditions and Transitional influences, ed. J. S. Bak and B. Reynolds (Amhearst and Boston: University of Massachusetts Press, 2011), 131.

41. Vanda Cristina Rosa, A cidade de Lisboa no Jornalismo Literário de Fialho de Almeida. PhD Dissertation. (Lisboa: ISCPS, 2019), 47.

42. Melissa Jean Score, The Development and Impact of Campaigning Journalism in Britain, 1840-1875: The Old New Journalism [Thesis] (University of London, 2015), 3.

43. About this issue, see Alain Vaillant, "La presse au miroir de la littérature," in Presse \& Plumes. Journalisme et Littérature au XIX ${ }^{\mathrm{e}}$ siècle, ed. Marie-Ève Thérenty and Alain Vaillant. (Paris: Nouveau-Monde Editions, 2004): 13-15.

44. We have but to recall Balzac's famous text of 1843, Monographie de la Presse Parisienne, or even the articles that Stendhal published in British magazines, in which he makes a penetrating analysis of the French press to see that both were aware that the price to be paid for media attention was too high.

45. Regeneration is the name given to the period in the history of the Portuguese constitutional monarchy between 1851 and 1868, led by Fontes Pereira de Melo. It was a period of development and modernisation for the country. 
46. According to José Tengarrinha, 'the Regeneration opened up a period of great opportunities for the press through the promulgation of several laws, among which we highlight the following: the Act of 24 May 1851, which determined the annulment of all the cases filed by the Public Prosecutor relating to the abuse of freedom of the press; the Act of 8 July 1851, which regulated literary property (...); the Act of 1 October 1856, which established that the laws on freedom of the press should be enforced also in the Portuguese overseas territories.' Tengarrinha, História da Imprensa, 184.

47. Eça de Queirós, Textos de Imprensa II (do Distrito de Évora) (Lisboa: INCM, 2019): 86.

48. This text-“Palavras sobre o jornalismo constitucional” (Words about constitutional journalism)was published in 1870 in issue 17 of the newspaper A República, founded and edited by Oliveira Martins. Although it is unsigned, Lopes de Oliveira ascribed it to Eça de Queirós. See Ernesto Guerra da Cal, Lengua y Estilo de Eça de Queiroz-Apêndice Bibliografía Queirociana sistemática y anotada e iconografia artística del hombre y la obra, Tomo $1^{\circ}$ (Coimbra: Imprensa da Universidade de Coimbra, 1975): 176.

49. About this, see Broersma, "Journalism as Performative Discourse”.

50. Ferenczi, L'invention du journalisme, 235

51. On the significance of the work of Gabriel Tarde and Gustave Le Bon, see Pascal Durand, "Presse ou médias, littérature ou culture médiatique? Question de concept,” ConTextes, 11 (2012), 7-11.

52. Eça de Queirós, Cartas Públicas (critical edition by Ana Teresa Peixinho). (Lisboa: INCM, 2009), 189.

53. According to Marie-Ève Thérenty, 'le roman-feuilleton représente à la fois une victoire pour l'écrivain de fiction (victoire économique et idéologique) et une défaite (défaite esthétique dans la mesure où la production tente de s'ajuster le plus étroitement possible à l'attente d'un public). Dans l'écriture du roman-feuilleton l'écart par rapport à l'horizon d'attente est minimal et les effets de surprise, si prenants dans l'intrigue, sont des effets poétiques maîtrisés, prévus et pour tout dire très conventionnels.' (Marie-Ève Thérenty, Mosaïques. Être écrivain entre presse et roman (1829-1836) (Paris: Honoré Champion, 2003), 13).

54. Analysing the emergence of the new journalistic genre, in the great report, very expressive at the end of the century, Christian Delporte established a parallel between this and the naturalist current, of which Zola is the greatest exponent (Christian Delporte, Les journalistes en France 1880-1950. Naissance et construction d'une profession (Paris: Ed. du Seuil, 1999), 68-72).

55. For an overview, see Alan Freeland, “Eça de Queirós e a Inglaterra”, in 150 anos com Eça de Queirós, III Encontro Internacional de Queirosianos. (São Paulo, Centro de Estudos Portugueses, Faculdade de Filosofia, Letras e Ciências Humanas, Universidade de São Paulo, 1995), 31-37, and Américo Guerreiro 
Sousa, “A Inglaterra na Obra de Eça de Queirós,” in Dicionário de Eça de Queirós. $2^{\text {nd }}$ ed. A. Campos Matos (Lisboa Editorial Caminho, 1993), 527-530.

56. For an overview, see Cristophe Charle, "Nascimento dos intelectuais," Revista História da Educação, no. 14 (Jul./dez. 2003), 141-156, and Dominique Kalifa; Philippe Régnier; Marie-Ève Thérenty and Alain Vaillant. (Dirs.). La Civilisation du Journal'. Histoire Culturelle et Littéraire de la Presse au XIX ${ }^{\mathrm{e}}$ Siècle. (Paris: Nouveau Monde Editions, 2011).

\section{Biography}

Ana Teresa Peixinho holds a PhD in Communication Science from University of Coimbra, where she is professor at the Faculty of Arts and Humanities. She is researcher at CEIS20-Center for Interdisciplinary Studies, where she coordinates, with Clara Almeida Santos, the research group Communication, Journalism and Public Sphere. Her research focuses on Media Narrative Studies and Media Analysis. She is also a research collaborator at the Centre for Portuguese Literature, where she is a team member of the “Critical Edition of Eça de Queirós’s Works”.

\section{TMG Journal for Media History}

Volume 24 No $(1 / 2) / 2021$

\section{DOI}

https://dx.doi.org/10.18146/tmg.780

\section{PUBLISHER}

Netherlands Institute for Sound and Vision

\section{COPYRIGHT}

Each article is copyrighted (c) by its author(s) and is published under license from the author(s). When a paper is accepted for publication, authors will be requested to agree with the Creative Commons Attribution 4.0 International License. 